\title{
Analysis on financing structure and default probability of listed companies
}

\author{
Xiangyun $\mathrm{Luo}^{1, *}$ Miao $\mathrm{Luo}^{2}$ \\ ${ }^{1}$ Beijing Jiaotong University, School of Economics and Management, Haidian, Beijing, China \\ ${ }^{2}$ Beijing Jiaotong University, School of Economics and Management, Haidian, Beijing, China
}

\begin{abstract}
This paper studies the relationship between the financing structure and the probability of default of A-share listed companies from 2001 to 2020 . The purpose is to prevent the occurrence of default and ensure the healthy development of various industries. It is found that the higher the proportion of external financing is, the higher the probability of default is. The impact of debt financing on default risk is higher than equity financing. In addition, this paper tests the mediating effect of cash flow risk, and the effect of financing structure on debt default probability is heterogeneous among regions and enterprises. These findings show that enterprises must control their financing structure, optimize the allocation of resources, prevent cash flow risk, reduce the probability of debt default, so as to make various industries flourish and optimize the industrial structure.
\end{abstract}

\section{Introduction}

Since the "11 super day debt" default event occurred in 2014, China's debt default events emerge in an endless stream, from the beginning concentrated in private enterprises, and gradually expanded to the whole body of enterprises. According to the data released to the public, the amount of default involved by each default subject will exceed 100 billion yuan, and the scope of debt default events will be further expanded.

In addition to the damage to the interests of the enterprise itself ${ }^{[1][2]}$, but also infringe on the interests of corporate stakeholders ${ }^{[3]}$. At present, the research less on the impact of corporate financing structure on debt default. Chiu ${ }^{[4]}$ and other research results show that during the financial crisis, the default risk of enterprises relying on bank financing is higher than that of other enterprises. The results show that debt financing has an impact on the probability of default. This paper extends the research object to corporate financing structure, and adds the data during the non-financial crisis to further study the impact of corporate financing structure on debt default probability.

The operating conditions of enterprises restrict whether enterprises can repay their debts on time. Previous studies have shown that the financing structure is the factor affecting the operating conditions of companies. Increasing debt financing ${ }^{[5]}$ and endogenous financing ${ }^{[6]}$ is conducive to the operation of enterprises. On the other hand, the financing structure also affects the cash status of enterprises. The amount of funds obtained by external financing is large, but the corresponding financing cost is high and the repayment pressure is high. Based on the above analysis, this paper will focus on the impact of corporate financing structure on debt default probability, explore the impact of different sources of financing on debt default probability, and further explore the mediating role of cash flow risk between them.

\section{Materials and methods}

\subsection{Theoretical analysis and hypothesis}

Basis of information asymmetry theory in 1984. This theoretical hypothesis fully considers the cost of obtaining funds for enterprises, and thinks that enterprises should first use their own surplus, and then consider external financing when they are insufficient.

The proportion of internal financing can reflect the enterprise's own operating conditions. When enterprises conduct external financing, it shows that the existing amount of funds is not enough to support the operation and development of the enterprise. On the one hand, it may be due to the expansion of the enterprise operation, which needs more capital investment. On the other hand, it may be due to the poor operation of the enterprise, which needs capital investment to maintain its survival. Under the influence of information asymmetry theory and incomplete contract theory, it is difficult for the external investors to fully understand the business situation when they invest, so they are bound to bear certain risks. When an enterprise uses external financing to expand its scale, its internal environment will change to meet the demand. At the same time, due to the unpredictable external environment, the risk of business failure will increase, so the probability of default is high; When an enterprise uses external financing for the purpose of maintaining its own

\footnotetext{
*Corresponding author: 20120665@bjtu.edu.cn
} 
operation, it shows that its own operation problems lead to insufficient funds, and the probability of default is high. Based on the above analysis, hypothesis 1 and 2 are proposed

$\mathrm{H} 1$ : with other conditions unchanged, the proportion of internal financing of listed companies is negatively correlated with the probability of default.

$\mathrm{H} 2$ : with other conditions unchanged, the proportion of external financing of listed companies is positively correlated with the probability of debt default.

When enterprises conduct external financing, they consider the tax shield effect of debt and the possibility of dispersing shareholders' power, and the order of external debt financing is prior to equity financing. However, most of the listed companies in China distribute little or no dividend when they issue stocks, but there are clear interest rates in debt financing. From the perspective of enterprise development, in the Chinese market environment, equity financing does not need to repay

$$
\text { Risk }=\frac{1}{1+e^{-\left(-0.867+2.5313 x_{1}-40.2785 x_{2}+0.4597 x_{3}+3.2293 x_{4}-3.9544 x_{5}-1.7814 x_{6}\right)}}
$$

\subsubsection{Independent variable}

Referring to most studies, this paper divides the financing structure into internal financing (ine) and external financing (out), in which the external financing is further divided into debt financing and equity financing, and the proportion is debt equity financing proportion (de). The specific calculation method is shown in Table 1.

\subsubsection{Control variable}

For the selection of control variables, refer to the common practices in relevant research, select the return on assets (roa), financial leverage (lev), proportion of fixed assets (tang), current ratio (current), growth (growth), operating cash flow (cf), executive bank background (bankie) to measure. The specific calculation method is shown in Table 1

\subsubsection{Mediator}

Referring to Hua Fengtao and $\mathrm{Xu} \mathrm{Fei}^{[8]}$, the intermediate variable cash flow risk is measured by the standard deviation of net cash flow per share of operating activities for three consecutive natural years.

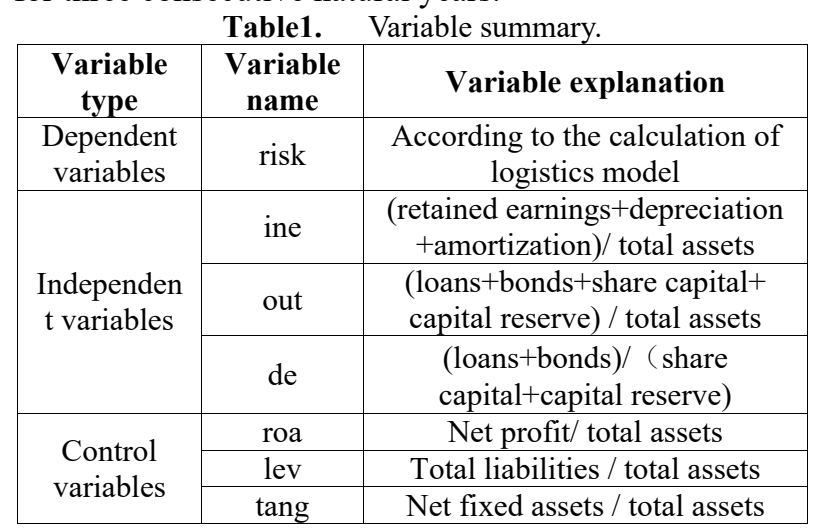

equity, and the probability of dividend is not high, and equity financing to join more shareholders is conducive to the development of the company ${ }^{[7]}$. Based on the above analysis, hypothesis 3 is proposed

H3: with other conditions unchanged, the debt equity financing ratio of listed companies is positively correlated with the probability of debt default.

\subsection{Variable description}

\subsubsection{Dependent variable}

At present, zscore value model (Altman, 1968), KMV model, B-S model and logistics regression model are widely used to calculate the default probability of corporate debt. This paper calculates the default risk of corporate debt by referring to the logistics model defined by Wu Shinong and Tan Chunzhi.

\begin{tabular}{|c|c|c|}
\hline $\begin{array}{c}\text { Variable } \\
\text { type }\end{array}$ & $\begin{array}{c}\text { Variable } \\
\text { name }\end{array}$ & Variable explanation \\
\hline \multirow{7}{*}{ current } & $\begin{array}{c}\text { Current assets / current } \\
\text { liabilities }\end{array}$ \\
\cline { 2 - 3 } & growth & $\begin{array}{c}\text { Growth rate of current operating } \\
\text { revenue }\end{array}$ \\
\cline { 2 - 3 } & cf & $\begin{array}{c}\text { Cash flow from operating } \\
\text { activities / total assets }\end{array}$ \\
\cline { 2 - 3 } & bankie & $\begin{array}{c}\text { If the executive has bank } \\
\text { background, the value is 1. }\end{array}$ \\
\hline
\end{tabular}

\subsection{Empirical model}

This paper adopts the following model to investigate the impact of corporate financing structure on debt default probability.

$$
\begin{aligned}
& \text { risk }_{i, t}=\alpha_{0}+\alpha_{1} \text { ine }_{i, t}+\text { controls }_{i, t}+\text { year }+ \text { ind }+\varepsilon_{i, t} \\
& \text { risk }_{i, t}=\alpha_{0}+\alpha_{1} \text { out }_{i, t}+\text { controls }_{i, t}+\text { year }+ \text { ind }+\varepsilon_{i, t} \\
& \text { risk }_{i, t}=\alpha_{0}+\alpha_{1} \text { de }_{i, t}+\text { controls }_{i, t}+\text { year }+ \text { ind }+\varepsilon_{i, t}
\end{aligned}
$$

\subsection{Data sources and descriptive statistics}

This paper selects all A-share listed companies in China from 2000 to 2020 as the research object, and in order to ensure the stability of the data, it carries out the following processing:(1) remove all st enterprises ;(2) excluding the listed financial enterprises;(3)eliminate the enterprises with serious lack of data;(4)the data were tailed at $1 \%$ quantile. All the data are from guotaian database, and Stata is used for data processing.

Table2. Descriptive statistics.

\begin{tabular}{|c|c|c|c|c|c|c|}
\hline variable & $\mathbf{N}$ & mean & sd & p50 & min & max \\
\hline risk & 11141 & 0.1941 & 0.3175 & 0.0272 & 0.0000 & 1.0000 \\
\hline ine & 11141 & 0.1898 & 0.1568 & 0.1858 & -0.4750 & 0.5843 \\
\hline out & 11119 & 0.5511 & 0.1886 & 0.5489 & 0.1356 & 1.2004 \\
\hline de & 11119 & 1.0418 & 1.5342 & 0.5146 & 0.0000 & 8.9646 \\
\hline stcf & 11141 & 0.4691 & 0.5575 & 0.2791 & 0.0154 & 3.2524 \\
\hline roa & 11141 & 0.0399 & 0.0545 & 0.0365 & -0.2017 & 0.1939 \\
\hline lev & 11141 & 0.4474 & 0.2051 & 0.4479 & 0.0540 & 0.8801 \\
\hline tang & 11141 & 0.2234 & 0.1688 & 0.1878 & 0.0019 & 0.7149 \\
\hline
\end{tabular}




\begin{tabular}{|c|c|c|c|c|c|c|}
\hline current & 11141 & 2.2667 & 2.3546 & 1.5592 & 0.2964 & 15.8218 \\
\hline growth & 11141 & 0.1819 & 0.3944 & 0.1159 & -0.5152 & 2.4463 \\
\hline cf & 11141 & 0.0478 & 0.0716 & 0.0474 & -0.1718 & 0.2470 \\
\hline banktie & 11141 & 0.3015 & 0.4589 & 0.0000 & 0.0000 & 1.0000 \\
\hline
\end{tabular}

From the descriptive results, we can see that the risk of debt default is still widespread in listed companies. The average probability of debt default is $19.41 \%$, and there are significant differences between different companies. From the perspective of corporate financing structure, China's listed companies use more external financing than internal financing, which is also related to the smaller amount of internal financing itself. In the external financing, the proportion of debt financing is significantly higher than that of equity financing, but different enterprises still have different preferences for the choice of financing channels. The descriptive statistical results of other control variables are not significantly different from the common results of scholars.

\section{Results \& discussion}

\subsection{Basic regression analysis}

From the benchmark regression results in Table 3, we can see that the coefficient of internal financing in the first column is -0.4587 , which is significant at the significance level of $1 \%$, indicating that there is a negative correlation between internal financing and debt default probability, which verifies the hypothesis 1 of this paper. The coefficient of the second column of external financing is 0.3816 , which is significant at the $1 \%$ significance level, indicating that the external financing of enterprises is positively correlated with the probability of debt default, which verifies the hypothesis 2 of this paper. In the third column, the coefficient of debt equity financing ratio is 0.0376 , which is significant at the $1 \%$ significance level, indicating that the debt equity financing ratio is positively correlated with the debt default probability, which verifies hypothesis 3 .

Table3. Basic regression results.

\begin{tabular}{|c|c|c|c|}
\hline & (1) & (2) & (3) \\
\hline & risk & risk & risk \\
\hline ine & $\begin{array}{c}-0.4587 * * * \\
(-16.124)\end{array}$ & & \\
\hline out & & $\begin{array}{c}0.3816^{* * *} \\
(19.851)\end{array}$ & \\
\hline de & & & $\begin{array}{c}0.0376 * * * \\
(14.098)\end{array}$ \\
\hline roa & $\begin{array}{c}-0.1700 * * \\
(-2.117)\end{array}$ & $\begin{array}{c}-0.2025 * * * \\
(-2.594)\end{array}$ & $\begin{array}{c}-0.9770 * * * \\
(-13.125)\end{array}$ \\
\hline lev & $\begin{array}{c}0.5278 * * * \\
(22.320)\end{array}$ & $\begin{array}{c}0.6936^{* * *} \\
(31.181)\end{array}$ & $\begin{array}{c}0.4121 * * * \\
(14.690)\end{array}$ \\
\hline $\operatorname{tang}$ & $\begin{array}{c}0.3573 * * * \\
(17.270)\end{array}$ & $\begin{array}{c}0.2374 * * * \\
(11.279)\end{array}$ & $\begin{array}{c}0.2854 * * * \\
(13.352)\end{array}$ \\
\hline current & $\begin{array}{c}0.0542 * * * \\
(29.404)\end{array}$ & $\begin{array}{c}0.0514 * * * \\
(27.578)\end{array}$ & $\begin{array}{c}0.0497 * * * \\
(25.847)\end{array}$ \\
\hline growth & $\begin{array}{c}0.1507 * * * \\
(13.535)\end{array}$ & $\begin{array}{c}0.1539 * * * \\
(13.816)\end{array}$ & $\begin{array}{c}0.1737 * * * \\
(15.880)\end{array}$ \\
\hline $\mathrm{cf}$ & $\begin{array}{l}-0.0494 \\
(-1.040)\end{array}$ & $\begin{array}{l}0.0304 \\
(0.630)\end{array}$ & $\begin{array}{l}-0.0563 \\
(-1.170)\end{array}$ \\
\hline banktie & $\begin{array}{c}0.0145^{* *} \\
(2.549)\end{array}$ & $\begin{array}{c}0.0126 * * \\
(2.219)\end{array}$ & $\begin{array}{l}0.0094 * \\
(1.647)\end{array}$ \\
\hline
\end{tabular}

\begin{tabular}{|c|c|c|c|}
\hline cons & $\begin{array}{c}-0.1779 * * * \\
(-6.075)\end{array}$ & $\begin{array}{c}-0.5267 * * * \\
(-16.728)\end{array}$ & $\begin{array}{c}-0.1488^{* * *} \\
(-4.942)\end{array}$ \\
\hline $\mathrm{N}$ & 11141 & 11119 & 11119 \\
\hline $\mathrm{r} 2 \_\mathrm{a}$ & 0.2771 & 0.2856 & 0.2717 \\
\hline \multicolumn{3}{|c|}{$\mathrm{t}$ statistics in parentheses $=" * \mathrm{p}<0.1 * * \mathrm{p}<0.05 * * * \mathrm{p}<0.01 "$} \\
\hline
\end{tabular}

\subsection{Intermediary mechanism analysis}

The first regression is the basic regression, which has been verified in the previous paper. It shows that there is a significant correlation between financing structure and debt default probability; In the second regression, the intermediary variable cash flow risk and the explanatory variable financing structure are regressed to investigate the influence of financing structure and cash flow risk; The third regression is to test the mediating mechanism by adding mediating variables into benchmark regression. stcf $_{i, t}=\alpha_{0}+\alpha_{1}$ ine $_{i, t}+$ controls $_{i, t}+$ year + ind $+\varepsilon_{i, t}$ stcf $_{i, t}=\alpha_{0}+\alpha_{1}$ out $t_{i, t}+$ controls $_{i, t}+$ year + ind $+\varepsilon_{i, t}$ stcf $_{i, t}=\alpha_{0}+\alpha_{1}$ de $_{i, t}+$ controls $_{i, t}+$ year + ind $+\varepsilon_{i, t}$ risk $_{i, t}=\alpha_{0}+\alpha_{1}$ ine $_{i, t}+\alpha_{2}$ stcf $_{i, t}+$ controls $_{i, t}+$ year + ind $+\varepsilon_{i, t}$ risk $_{i, t}=\alpha_{0}+\alpha_{1}$ out $_{i, t}+\alpha_{2}$ stcf $_{i, t}+$ controls $_{i, t}+$ year + ind $+\varepsilon_{i, t}$ risk $_{i, t}=\alpha_{0}+\alpha_{1} d_{i, t}+\alpha_{2}$ stcf $_{i, t}+$ controls $_{i, t}+$ year + ind $+\varepsilon_{i, t}$

From the regression results, we can see that the second regression shows that there is a significant correlation between the intermediary variable cash flow risk and the explanatory variable financing structure, and the constant coefficient is also significantly not 0 , indicating that there is a certain impact between the two. In the third regression, the coefficient of the explanatory variable is still significant, and does not change the test results of the original hypothesis, indicating that there may be a partial mediating effect between the two. However, because the coefficient of the intermediary variable is not significant in some cases, Sobel test is further carried out. The results of Sobel test are significant, indicating that there is indeed a partial mediating effect, that is, the financing structure affects the default probability of debt by affecting the cash flow risk.

\subsection{Robustness test}

\subsubsection{Replace explanatory variable}

Considering that the impact of corporate financing structure may lag behind, this paper regresses the explanatory variables of endogenous financing, external financing and debt equity financing ratio one year later, and the regression results still support the hypothesis of this paper.

\subsubsection{Control time, industry fixed effect}

In order to enhance the robustness of this study, considering the influence of time and industry development trend on the sample data, this paper controls the fixed effect of time and industry and makes regression. The regression result is still significant, and internal financing is negatively correlated with debt default probability; External financing, debt equity financing ratio and debt default probability are positively correlated, consistent with the previous conclusion. 


\subsection{Further research}

\subsubsection{The test of the nature of property rights}

Due to the participation of state capital in market operation, the nature of enterprise property rights in China can be roughly divided into state-owned enterprises and non-state-owned enterprises. At present, there has been a consensus in the academic circles that the nature of enterprise property rights will have an impact on enterprise operation. The regression results show that compared with non-state-owned enterprises, the financing structure of state-owned enterprises has a greater impact on the probability of default, which is reflected in the greater absolute coefficient of its explanatory variables. Then, we use Liao guanmin's research for reference ${ }^{[9]}$, multiply SOE and explanatory variables to get cross multiplicative term, and add it into regression to study the specific impact of property right. The test results further confirmed the regression results of grouping test.

\subsubsection{Regional inspection}

Limited by the location and terrain conditions, the economic development of the eastern and western regions of China is in an unbalanced state. The economic level of the eastern region is far higher than that of the western region. Listed companies in different regions are different because of regional economic environment. Although affected by China's macroeconomic environment, the level of regional economic development will also affect the development of enterprises. Moreover, in order to drive the development of the western region, the state has provided more supporting policies for the development of enterprises in the western region, which has also brought certain convenience for enterprise financing. Therefore, according to the division of the eastern, central and western regions in the general sense and the location information of listed companies, this paper divides them into three groups and regresses them respectively.

The regression results show that, although located in different regions, the coefficient and significance of the proxy variable of the overall financing structure are consistent with the benchmark test, indicating that the impact of financing structure on debt default probability is widespread in all regions. The external financing coefficient of the western region is significantly smaller than that of the eastern region, which may be due to the limited level of economic development.

\section{Conclusion}

The results show that the financing structure does have an impact on the probability of default. When the proportion of internal financing is high, the probability of default is low. Debt financing is the opposite. The reason is closely related to the environment of China's capital market. There are many and convenient ways for listed companies to raise debt capital. Under the influence of information asymmetry, creditors are prone to misjudge the business status of the enterprise and then lend funds, while the cost of raising debt funds is higher, which increases the capital pressure of the enterprise and leads to the increase of the probability of default. In order to ensure the continuous optimization of the industrial structure and the positive development of the industry, it is necessary to regulate the capital flow in the capital market and increase the quality of enterprise information disclosure.

\section{References}

1. MESSOD D. BENEISH, ERIC PRESS. Interrelation Among Events of Default*[J]. John Wiley \&amp; Sons, Ltd (10.1111),1995,12(1).

2. MICHAEL R. ROBERTS, AMIR SUFI. Control Rights and Capital Structure: An Empirical Investigation[J]. The Journal of Finance,2009,64(4).

3. SUDHEER CHAVA, MICHAEL R. ROBERTS. How Does Financing Impact Investment? The Role of Debt Covenants[J]. The Journal of Finance,2008,63(5).

4. Wan-Chien Chiu, Chih-Wei Wang,Juan Ignacio Peña. Does the source of debt financing affect default risk? [J]. Review of Financial Economics,2017.

5. Li Yang. The impact of financing scale structure on the performance of Listed Companies [J]. Management world, 2011 (04): 175-177

6. Kang Jun. research on the impact of financing structure on business performance of small and medium-sized board listed companies [J]. Friends of accounting, 2016 (16): 72-75

7. Li Huidong, Tang Yuejun, Zuo Jingjing. With their own money or with other people's moneyResearch on financing structure and corporate innovation of Listed Companies in China [J]. Financial research, 2013 (02): 170-183

8. Hua Fengtao, $\mathrm{Xu}$ Fei. How does environmental uncertainty affect corporate idiosyncratic risk: a test of mediating effect based on cash flow fluctuation and accounting information quality [J]. Nankai management review, 2018,21 (04): 122-133

9. Liao guanmin, Tang Yiyu, Wu Xi. Operational risk, property right nature, bank competition and corporate debt maturity structure: An Empirical Test Based on liquidity risk theory $[\mathrm{J}]$. China Accounting and finance research, 2010, 012 (004): 1-75 